\title{
Analysis of the HNF4 $\alpha$ gene in Caucasian Type II diabetic nephropathic patients
}

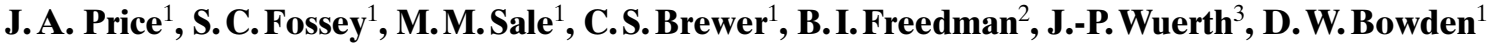 \\ ${ }^{1}$ Department of Biochemistry, Wake Forest University School of Medicine, Winston-Salem, North Carolina, USA \\ ${ }^{2}$ Department of Internal Medicine, Section of Nephrology, Wake Forest University School of Medicine, Winston-Salem, \\ North Carolina, USA \\ ${ }^{3}$ Alteon Inc., Ramsey, New Jersey, USA
}

\section{Abstract}

Aims/hypothesis. Linkage and association studies in Caucasian patients with Type II (non-insulin-dependent) diabetes mellitus suggest that one or more diabetes susceptibility gene(s) reside within human chromosome 20q12-13.1. This region of chromosome 20 contains the maturity-onset diabetes of the young type 1 gene, $H N F 4 \alpha$. The purpose of this study was to assess the possible involvement of $H N F 4 \alpha$ in Type II diabetes.

Methods. Mutation analysis was done on the 12 exons and promoter regions of the $H N F 4 \alpha$ gene in 182 Caucasian diabetic nephropathic patients and 100 Caucasian control subjects. The functional consequences of a novel promoter mutation were examined using a reporter system in the HepG2 liver cell line and electrophoretic mobility shift assays.

Results. We identified two novel mutations in the $\mathrm{HNF} 4 \alpha$, an $\mathrm{R} 323 \mathrm{H}$ missense mutation in exon 8 , and a $7 \mathrm{bp}$ deletion $(\Delta 7)$ in the proximal promoter region resulting in deletion of a single putative Sp1 binding site. Using a reporter assay system, the $\Delta 7$ sequence was found to exhibit a $51.2 \%$ (standard error \pm $4.2 \%$ ) reduction in promoter activity relative to the normal sequence. In electrophoretic mobility shift assays using specific and non-specific competitors, the $\Delta 7$ sequence had a $45.5 \%$ (range 40.4-46.6) reduction in binding compared with the normal sequence. The $\Delta 7$ allele occurs in a family with multiple cases of Type II diabetes in a pattern consistent with coinheritance of the $\Delta 7$ allele and diabetes.

Conclusion/interpretation. Analysis of the HNF4a gene revealed two possible mutations in 182 diabetic patients which suggests that the $H N F 4 \alpha$ gene does not make a large contribution to diabetes susceptibility in the general population of Caucasian diabetic nephropathic patients. Functional analysis of the $\Delta 7$ promoter deletion suggests, however, that promoter mutations in otherwise normal genes could contribute to diabetes susceptibility. [Diabetologia (2000) 43: 364-372]

Keywords Hepatocyte nuclear factor, Type II diabetes, transcription factors, gene expression, promoter.
Type II (non-insulin-dependent) diabetes mellitus is a common metabolic disorder characterised by hy-

Received: 22 April 1999 and in final revised form: 29 October 1999

Corresponding author: D.W. Bowden, Department of Biochemistry, Wake Forest University School of Medicine, Medical Center Blvd., Winston-Salem, NC 2715, USA

Abbreviations: HNF, Hepatocyte nuclear factor; MODY, maturity-onset diabetes of the young; EMSA, electrophoretic mobility shift assay; SSCP, single strand conformational polymorphism. perglycaemia, defects in insulin secretion and insulin resistance. This disease affects over 14 million people in the United States and over 100 million people worldwide [1]. Because Type II diabetes is considered a multifactorial disease resulting from numerous genetic and environmental factors, explaining the underlying molecular mechanisms contributing to the disease has been difficult. Recent genome-wide linkage studies have led to the localisation of two Type II diabetes susceptibility loci, NIDDM1 on chromosome $2 \mathrm{q}$ in Mexican Americans and NIDDM2 [2] on chromosome $12 \mathrm{q}$ in Finnish families [3]. Few repli- 
cate studies have, however, confirmed evidence of linkage in other ethnic populations, so the extent to which these genetic loci contribute to Type II diabetes susceptibility in the general population is not clear.

Maturity-onset diabetes of the young (MODY) is a rare autosomal dominant form of Type II diabetes. It accounts for only $2-5 \%$ of all cases of Type II diabetes and is characterised by an early age of onset $(<25$ years $)$ and primary defects in insulin secretion $[4,5]$. The recent cloning of five MODY genes have provided insight into factors regulating glucose homeostasis: hepatocyte nuclear factor 4 alpha $(H N F 4 \alpha)$ in MODY1 [6], glucokinase in MODY2 [7], hepatocyte nuclear factor 1 alpha $(H N F 4 \alpha)$ in MODY3 [8], insulin promoter factor $(I P F-1)$ in MODY4 [9], hepatocyte nuclear factor 1 beta $(H N F 1 \beta)$ in MODY5 [10]. Both $H N F 4 \alpha$ and $1 \alpha$ are transcription factors and are known to activate numerous genes involved in cholesterol, fatty acid, and glucose metabolism. They are expressed in a wide variety of tissue types including liver, kidney, small intestine, pancreas and muscle [11-12]. Although many different $H N F 1 \alpha$ mutations have been identified in MODY3 families [8, 13-19], only eight potential mutations in $H N F 4 \alpha$ (Q268X, R154X, R127W, V393I, E276Q, F75fsdelT, G115S, I454V) have been identified in MODY1 families [6, 20-25].

There have been four recent linkage studies evaluating American, French and Finnish Caucasian Type II diabetic families that have provided evidence of one, if not more than one, diabetes susceptibility locus on chromosome 20q12-13.1 (MODY1 region) [26-29]. In 1997, we reported evidence of linkage $(p<0.05)$ in Caucasian Type II diabetic sib-pairs to the polymorphic marker D20S197 [26]. A parallel study [27] reported evidence of linkage to three polymorphic markers in the MODY1 region (D20S119, D20S178, and D20S176) in Caucasian families with a preponderance of Type II affected members. Subsequently, evidence of linkage to polymorphic markers within, as well as, distal to the MODY1 region were reported in French Type II diabetic families [28]. In addition, the FUSION study (Finland-United States Investigation of NIDDM genetics), a large multicentre study consisting of 183 families with multiple Type II diabetic subjects, also observed linkage to chromosome 20 markers, namely D20S197 and a polymorphism near the adenosine deaminase gene $(A D A)$ [29]. All four of these studies observed evidence of linkage to the MODY1 region (20q12-13.1), although the regions with the maximum linkage scores differed between the studies.

In an effort to more precisely map these suspected Type II diabetes loci, our laboratory did a case-control linkage disequilibrium analysis [30]. Multiple genetic markers in 20q12-q13.1 were genotyped in 182 unrelated Caucasian Type II diabetic nephropathic patients and allele frequencies were compared with a set of 100 DNA samples from age-matched, non-diabetic, normal Caucasian control subjects. Significant evidence of disequilibrium $(p<0.005)$ was observed at the $A D A$ locus [30]. Because the MODY1 gene $(H N F 4 \alpha)$ resides in close proximity to the $A D A$ locus [31-33], we examined the Type II diabetic nephropathic patients in our studies for $H N F 4 \alpha$ mutations to assess whether $H N F 4 \alpha$ mutations could contribute to diabetes in this cohort.

\section{Subjects and methods}

Subjects. The study cohort consisted of 182 incident Caucasian diabetic nephropathic patients collected as part of a clinical trial sponsored by Alteon, Inc. (Aminoguanidine Clinical Trial in Overt Type 2 Diabetic Nephropathy). Patients enrolled in this study all had Type II diabetes mellitus with age of diagnosis after 35 years of age and overt proteinuria of more than $500 \mathrm{mg}$ protein in a $24-h$ period. Diabetic nephropathy was assigned as a diagnosis in the presence of diabetic retinopathy through renal biopsy. In addition to renal evaluation, each patient was evaluated by an ophthalmologist by fundus photography or ophthalmoscopy or both or evaluation of patient records. Men had an average initial serum creatinine of $114 \mu \mathrm{mol} / \mathrm{l}$ or more and women had an initial serum creatinine of $96.8 \mu \mathrm{mol} / \mathrm{l}$ or more. These subjects had an average $16.1 \pm 7.7$ years duration of diabetes (range 1-40 years), an average BMI of $33.0 \pm 6.2$ (range 20.3-52.3), and had diabetic nephropathy at the time blood samples were collected. No family history data for diabetes or nephropathy was available for the study group. The control group consisted of 100 unrelated non-diabetic Caucasian subjects who were employees of North Carolina Baptist Hospital of Wake Forest University. After informed consent had been given a blood sample was taken for DNA isolation at the time of recruitment. Genomic DNA was isolated using the Puregene DNA isolation kit (Gentra, Minneapolis, Minn., USA).

After the $\Delta 7$ allele was identified in one patient with diabetic nephropathy, this patient was contacted and provided his family history. He was one of eight children born to two parents affected by Type II diabetes (his mother was unaware of her diabetes at first interview and his diabetic father was deceased). His mother and all siblings agreed to be screened for the presence of diabetes and nephropathy and to provide DNA for genetic analysis.

Analysis of $H N F 4 \alpha$. The 12 exons, including splice junctions and $500 \mathrm{bp}$ of the proximal promoter region of $H N F 4 \alpha$ were analysed by PCR followed by single strand conformational polymorphism (SSCP) analysis in the patient and control samples [6, 21]. We used 15 primer sets to amplify 200-400 bp products for the analysis. For each reaction, both primers were end-labelled with $\left(\gamma-{ }^{32} \mathrm{P}\right)$ ATP by T4 polynucleotide kinase (Stratagene, La Jolla, Calif., USA) according to the manufacturers' instructions. We did PCR on $25 \mathrm{ng}$ of genomic DNA in a $15 \mu \mathrm{l}$ volume containing $50 \mathrm{mmol} / \mathrm{l} \mathrm{KCl}, 100 \mathrm{mmol} / \mathrm{l}$ TRIS-HCl pH $8.8,1.5 \mathrm{mmol} / \mathrm{l} \mathrm{MgCl}, 0.2 \mathrm{mmol} / \mathrm{l}$ deoxyribonucleoside triphosphates (dNTPs), 0.1 pmol end-labelled primers, 6 pmol of each unlabelled primer and $1.0 \mathrm{U}$ Taq polymerase. Samples were initially denatured for $5 \mathrm{~min}$ at $95^{\circ} \mathrm{C}$ and then cycled for 30 cycles of $40 \mathrm{~s}$ at $94^{\circ} \mathrm{C}, 40 \mathrm{~s}$ at annealing temperature ( $\mathrm{Tm}-3$ to $5^{\circ} \mathrm{C}$ ), $40 \mathrm{~s}$ at $72^{\circ} \mathrm{C}$, followed by $5 \mathrm{~min}$ at $72^{\circ} \mathrm{C}$ as a final elongation. After PCR amplification, the 


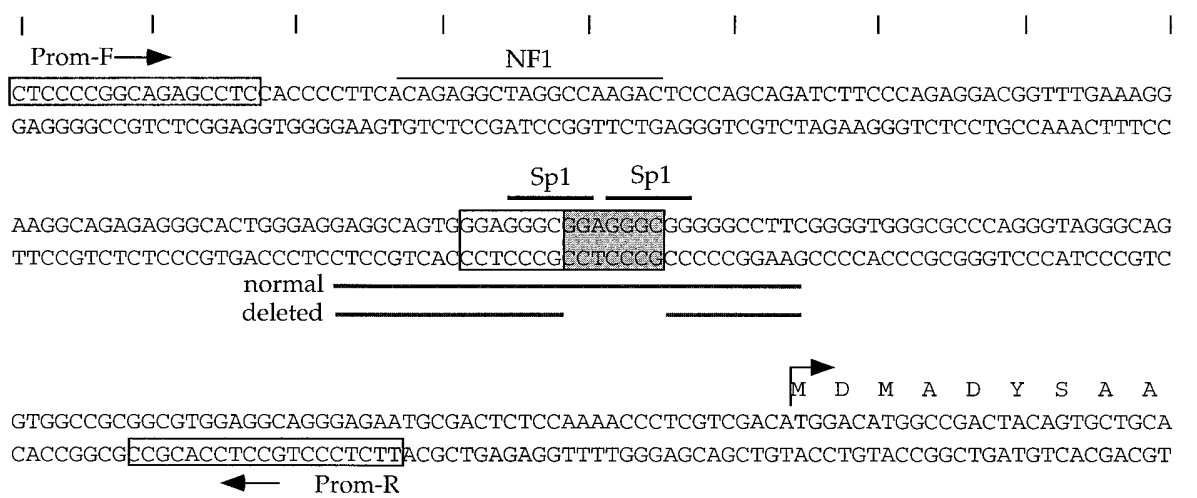

Fig.1. Human HNF4 $\alpha$ promoter sequence (Genbank HSHNF4AS01). The directly repeated 7 bp sequence is boxed; one half of this site is deleted in $\Delta 7$ (grey box). NF-1 and potential Sp1 binding sites are overlined. Primer sequences (Prom-F and Prom-R) used to generate the normal and deleted promoter sequences are boxed. An arrow denotes the initiator methionine. The normal and $\Delta 7$ sequences used in the electrophoretic mobility shift assay experiments are underlined in grey

products were diluted 1:10 in formamide loading dye (95\% formamide, $10 \mathrm{mmol} / \mathrm{l} \mathrm{NaOH}, 0.25 \%$ bromphenol blue, $0.25 \%$ xylene cylanol), denatured for $2 \mathrm{~min}$ at $95^{\circ} \mathrm{C}$ and immediately placed on ice. The PCR products $(1.7 \mu \mathrm{l})$ were separated by electrophoresis on 0.5X MDE acrylamide (FMC Bioproducts, Rockland, Md., USA), 0.6XTBE, $\pm 5 \%$ glycerol non-denaturing polyacrylamide gels at $25^{\circ} \mathrm{C}$ at $15 \mathrm{~W}$ for $15 \mathrm{~h}$. Gels were exposed to X-ray films overnight and checked for the presence of abnormal migration patterns. All products showing migration shifts and two products showing the predominant shift pattern were sequenced on both strands at the DNA Sequencing Core Laboratory of Wake Forest University School of Medicine using an ABI Prism 377 automated DNA sequencer (Applied Biosystems, Foster City, Calif., USA). Sequence similarity searching was carried out using the BLAST 2.0 analysis program ([34] http://www.ncbi.nlm.nih.gov/BLAST/).

Reporter constructs and transient transfection assays. The normal and $\Delta 7$ deletion mutant promoter sequences were amplified by PCR using primers: Prom-F primer 5 'CGGGGTACCCTCCCCGGCAGAGCCT-3' and Prom-R primer 5'-CGGAATTCTTCTCCCTGCCTCCACGCC-3' (Fig. 1) and subsequently digested with KpnI and EcoRI before cloning into the pSEAP2-Enhancer vector (Clontech, Palo Alto, Calif., USA). We grew HepG2 cells in DMEM (GibcoBRL, Rockville, Md., USA) supplemented with 10\% fetal calf serum (FCS) in $5 \% \mathrm{CO}_{2}$. Cells were transfected in triplicate in three independent experiments using a modified calcium phosphate method [35] with $10 \mu \mathrm{g}$ plasmid construct (pSEAP2-Enhancer \pm HNF4 $\alpha$ promoter sequences). Secreted alkaline phosphatase (SEAP) was measured using a chemiluminescence-luciferase assay (Clontech, Palo Alto, Calif., USA) according to manufacturers instructions $48 \mathrm{~h}$ after transfection. To normalise for transfection efficiency, $2 \mu \mathrm{g}$ cytomegalovirus-driven $\beta$-galactosidase expression plasmid was transfected simultaneously and $\beta$-galactosidase activity was measured $48 \mathrm{~h}$ after transfection [36].

Electrophoretic mobility shift assay (EMSA). Nuclear extracts were obtained from HepG2 cells. At $90 \%$ confluency, HepG2 cells were washed twice in PBS. Adherent cells were resuspended in $40 \mathrm{mmol} / \mathrm{l}$ TRIS (pH 7.5), $1 \mathrm{mmol} / \mathrm{l}$ EDTA, $150 \mathrm{mmol} / \mathrm{l} \mathrm{NaCl}$ by scraping. After a brief centrifugation, cells were washed twice in $10 \mathrm{mmol} / \mathrm{l} \operatorname{HEPES}(\mathrm{pH} 7.9), 1.5 \mathrm{mmol} / \mathrm{l}$ $\mathrm{MgCl}_{2}, 10 \mathrm{mmol} / 1 \mathrm{KCl}, 1 \mathrm{mmol} / 1$ dithiothreitol, $1 \mathrm{mmol} / 1 \mathrm{phen}-$ ylmethylsulphonyl fluoride, $2 \mu \mathrm{g} / \mathrm{ml}$ leupeptin (all from Sigma, St. Louis, Mo., USA) and homogenised with a Type A/B Dounce homogenizer. Cells were collected by brief centrifugation, resuspended in $20 \mathrm{mmol} / \mathrm{l} \mathrm{HEPES}$ ( $\mathrm{pH} 7.9$ ), $1.5 \mathrm{mmol} / 1$ $\mathrm{MgCl}_{2}, 400 \mathrm{mmol} / \mathrm{l} \mathrm{NaCl}, 10 \%$ sucrose, $20 \%$ glycerol, $0.2 \mathrm{mmol} / \mathrm{l}$ EDTA, $1 \mathrm{mmol} / 1$ phenylmethylsulfonyl fluoride (PMSF), $2 \mu \mathrm{g} / \mathrm{ml}$ leupeptin, and incubated on ice for $1 \mathrm{~h}$. Nuclei were collected by centrifugation at $23000 \times g$ for $60 \mathrm{~min}$ at $4{ }^{\circ} \mathrm{C}$. Nuclear proteins were recovered by overnight dialysis against $20 \mathrm{mmol} / 1 \mathrm{HEPES}, 1.5 \mathrm{mmol} / 1 \mathrm{MgCl}_{2} 20 \%$ glycerol, $0.2 \mathrm{mmol} / 1 \mathrm{EDTA}, 1 \mathrm{mmol} / \mathrm{l}$ dithiothreitol, $1 \mathrm{mmol} / \mathrm{l} \mathrm{PMSF}$ and $2 \mu \mathrm{g} / \mathrm{ml}$ leupeptin (Buffer C). The nuclear proteins were collected and the protein concentrations were determined by the Bradford assay (Bio-Rad laboratory, Hercules, Calif., USA). Complimentary oligonucleotides representing consensus Sp1 5'-ATTCGATCGGGGCGGGGCGAGC-3' [37], TFIID 5'-GCAGAGCATATAAGGTGAGGTAGGA-3' [37], normal promoter 5'-GAGGCAGTGGGAGGGCGGAGGGCGGGGGCCTT-3 ' and mutant promoter 5 '-GAGGCAGTGGGAGGGCGGGGGCCTT- ${ }^{\prime}$ ' were annealed and 4 pmols were 5 'end-labelled with $\left(\gamma-{ }^{32} \mathrm{P}\right)$ ATP using T4 polynucleotide kinase (Stratagene, La Jolla, Calif., USA) according to the manufacturer's protocol. Binding reactions were done by pre-incubating $5 \mu \mathrm{g}$ of nuclear extract proteins with or without unlabelled competitor DNA (at $10 \times, 25 \times$, or $50 \times$ excess) in Buffer C plus $1 \mu \mathrm{g}$ poly $\mathrm{dI} / \mathrm{dC}$ for $10 \mathrm{~min}$ on ice in a $30 \mu \mathrm{l}$ volume. Double stranded end-labelled oligonucleotide (40 fmol) was then added and incubated for $30 \mathrm{~min}$ on ice. Loading dye was added and $7 \mu$ l of the samples were loaded onto a $5 \%$ polyacrylamide gel (29:1 acrylamide:bisacrylamide $)+1.25 \%$ glycerol prepared in $0.5 \mathrm{XTBE}$. Electrophoresis was done at $4{ }^{\circ} \mathrm{C}$ and $250 \mathrm{~V}$ for $2 \mathrm{~h}$. Gels were fixed in $10 \%$ acetic acid $/ 10 \%$ isopropanol, dried and analysed using a Phosphor Imager 445 SI (Molecular Dynamics, Sunnyville, Calif., USA). Bound complexes were quantified from six independent experiments.

Genotyping and clinical evaluation of the WFUBMC $2137(\Delta 7)$ family. All first-degree adult relatives of the $\Delta 7$ proband were evaluated for the presence of the $\Delta 7$ mutation and for clinical measures of Type II diabetes and nephropathy. Family members participated in the study after informed consent was obtained. Genotype analysis was carried out by PCR amplification of the proximal promoter region for each individual DNA sample, followed by SSCP analysis. The normal and $\Delta 7$ deletion mutant promoter sequences were amplified from each of them by PCR using the following $\left[\gamma_{-}{ }^{32} \mathrm{P}\right] \mathrm{dATP}$ (ICN 
Table 1. Human HNF4 $\alpha$ DNA mutations or polymorphisms or both in Caucasian subjects. Allele frequencies were determined in 182 Caucasian Type II diabetic nephropathic patients (364 chromosomes) and 100 unrelated Caucasian control subjects (200 chromosomes)

\begin{tabular}{|c|c|c|c|c|c|}
\hline Exon/Intron & ${ }^{\mathrm{b}}$ Location & Nucleotide change & Amino acid change & Type II diabetes & Control \\
\hline${ }^{\mathrm{a}}$ Promoter & nt 1066-1071 & del GGAGGGC & & $.002 / .998$ & 0 \\
\hline Intron $1 \mathrm{~A}$ & nt 1288 & $\mathrm{G} \rightarrow \mathrm{A}$ & & $.05 / .95$ & $.04 / .96$ \\
\hline Exon $1 \mathrm{C}$ & nt 1563 & $\mathrm{G} \rightarrow \mathrm{A}$ & $\mathrm{Val} \rightarrow \mathrm{Met}$ & $.11 / .89$ & $.08 / .92$ \\
\hline Intron $1 \mathrm{~B}$ & nt 3175 & $\mathrm{C} \rightarrow \mathrm{T}$ & & $.21 / .79$ & $.26 / .74$ \\
\hline Exon 4 & nt 114 & $\mathrm{C} \rightarrow \mathrm{T}$ & $\mathrm{Thr} \rightarrow$ Ile & $.03 / .97$ & $.01 / .99$ \\
\hline${ }^{\mathrm{a}}$ Exon $8 \mathrm{~B}$ & nt 718 & $\mathrm{G} \rightarrow \mathrm{A}$ & $\mathrm{Arg} \rightarrow \mathrm{His}$ & $.002 / .998$ & 0 \\
\hline
\end{tabular}

${ }^{a}$ newly identified mutations.

${ }^{\mathrm{b}}$ nt, nucleotides; nucleotide numbers refer to Genbank HSHNF4AS01. Previously identified mutations or polymorphisms or both are referenced

Radiochemicals, Irvine, Calif., USA) end-labelled primers: HNF $\triangle 2 \mathrm{~F}$ primer 5'-CCACCCCTTCACAGAGGCTA-3' HNF $\Delta 1 \mathrm{R}$ primer 5 '-CAGTGCAGCACTGTAGTCGG-3'. The PCR products were denatured and analysed by electrophoresis on denaturing $8 \%$ polyacrylamide gels at $60 \mathrm{~W}$ for $3 \mathrm{~h}$. Gels were exposed overnight to x-ray film (Fuji, Stamford, Conn., USA) between intensifying screens. Clinical analysis consisted of measurement of glycated haemoglobin concentration, urine protein:creatinine ratio, serum creatinine and blood urea nitrogen concentrations. Data on age, height, weight and age of diagnosis of diabetes were collected along with the patients initial and current diabetic therapy (diet, insulin, oral agents) and anti-hypertensive (angiotensin converting enzyme inhibitor) therapy.

\section{Results}

Previous linkage and linkage disequilibrium studies from this and other laboratories have suggested the presence of at least one, possibly two, Type II diabetes susceptibility loci on chromosome 20q12-13.1 [26-29]. Due to the previous identification of the $H N F 4 \alpha$ as a diabetogenic gene, we did mutation analysis of the $H N F 4 \alpha$ gene in 182 unrelated Type II diabetic nephropathic patients which in an earlier study [30] exhibited significant evidence of linkage disequilibrium to an allele of a polymorphic marker $(A D A)$ residing in close proximity to the HNF4 $\alpha$ gene. The results of these analyses are shown in Table 1 . Within introns $1 \mathrm{~A}$ and $1 \mathrm{~B}$ three previously reported polymorphisms were identified in both patient and control samples and two reported coding changes in exons $1 \mathrm{C}$ and 4 were also identified $[38,39]$. No differences in the frequencies of the polymorphisms or mutations or both were observed between the Type II diabetic patients and control groups, corroborating results from other studies $[21,22,38]$. We identified two novel alleles in the Type II diabetic patient group, a 7 bp deletion (denoted $\Delta 7$ ) in the promoter region and an $\mathrm{Arg} \rightarrow$ His mutation $(\mathrm{R} 323 \mathrm{H})$ in exon 8 . These two mutations were not present in the 100 control samples.

One patient carried a 7 bp deletion $(\Delta 7)$ in the promoter region of $H N F 4 \alpha$. This patient had a BMI of
44.2 and age of onset of 35 years. The $\Delta 7$ mutation occurred 102 bp upstream from the initiation codon. The deleted 7 base pairs ( $5^{\prime}-$ GGAGGGC- 3 ') are half of a direct repeat from the normal promoter sequence which contains two copies of the motif in a head to tail orientation (Fig. 1). The 14 base pairs of the normal $H N F 4 \alpha$ promoter (5'-GGAGGGC$3^{\prime} \times 2$ ) corresponds to two putative consensus binding sites for the $\mathrm{Sp} 1$ transcription factor $\left(5^{\prime}-\mathrm{N}(\mathrm{G} /\right.$ A)GGCGN(G/A)N-3') (Fig.1). The $\Delta 7$ promoter contains only one consensus Sp1 binding site. Sp1 is a ubiquitously expressed transcription factor known to activate the transcription of numerous genes [40]. Deletion of clustered or isolated Sp1 sites from the promoter regions of genes can affect the transcriptional activation [41-44]. Consequently, observation of the $\Delta 7$ mutation in a diabetic subject suggested that altered expression of a normal $\mathrm{HNF} 4 \alpha$ gene could be involved in diabetes susceptibility in this subject.

The effect of the $\Delta 7$ mutation on promoter activation was analysed using a reporter gene assay. A 187base pair fragment of the normal HNF4 $\alpha$ and a 180base pair fragment the $\Delta 7$ promoter region were amplified by PCR (Prom-F to Prom-R in Fig. 1) and cloned into the pSEAP2-Enhancer vector (Clontech, Palo Alto, Calif., USA). This minimal promoter region contained the putative Sp1 binding site(s) and the NF1 transcription factor binding site [17]. Normal, $\Delta 7$, and control reporter constructs were transfected into HepG2 liver cells and secreted alkaline phosphatase representing promoter activity was measured. The construct containing the $\Delta 7$ allele resulted in a $51.2 \%$ (standard error $\pm 4.1 \%$ ) reduction in promoter activity relative to the intact sequence containing two Sp1 sites (Fig. 2).

Electrophoretic mobility shift assays (EMSA)/gel retardation assays, using specific and non-specific oligonucleotide competitors, were done to evaluate the effect of the $\Delta 7$ allele on transcription factor binding to recognition sequences (Fig. 3). Three retarded complexes, (Fig. 3A) were observed when radiola- 


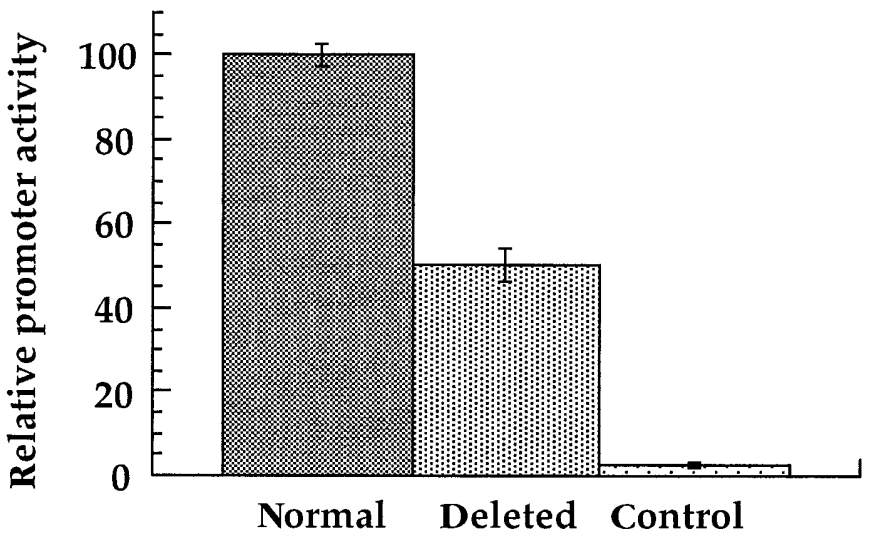

pSEAP2-Enhancer construct

Fig. 2. Reduction of promoter activity in $\Delta 7$ promoter. pSEAP2 Enhancer + normal $(\mathrm{N}),+\Delta 7$, and alone (control) were transfected into HepG2 cells along with pCMV $\beta$-Gal. Secreted alkaline phosphatase, representing promoter activity, was measured at $48 \mathrm{~h}$ and normalised to $\beta$-gal activity. All three independent transfections were done in triplicate with the normal construct representing $100 \%$ activity (means \pm SEM, $n=3$ )

belled normal sequence (Fig. 1) was incubated in the presence of HepG2 nuclear extracts. All three bands were specifically competed away using the unlabelled normal sequence. By comparison, competition of the radiolabelled normal sequence with unlabelled $\Delta 7 \mathrm{se}$ quence resulted in an average $45.5 \%$ (range $40.4 \%$ to $46.5 \%$ ) less efficient competition in concentrations from 2 to 50 -fold excess of labelled normal sequence (Fig.3B). Similar migrating protein-DNA complexes were observed when a radiolabelled consensus Sp1 sequence was used as a probe in the gel retardation assays (arrows in Fig. 3C). When unlabelled normal and $\Delta 7$ sequences were used as competitors in the binding assays with labelled Sp1, all bands were specifically competed with the $\Delta 7$ sequence showing an average $47.3 \%$ (range $35.8 \%$ to $51.4 \%$ ) less efficient competition at competitor concentrations from 5 to 75 -fold (Fig. 3D). When recombinant human Sp1 protein (Promega, Madison, Wis., USA) was used in place of the nuclear extract, similar protein-DNA complexes, three shifted bands, were observed (data not shown). These results indicate that proteins bind the normal sequence more efficiently than the deleted sequence.

In addition to the molecular evaluation of the $\Delta 7$, we have evaluated the effect of this putative mutation by genotyping additional family members. The family has been designated WFUBMC 3137. Segregation of the $\Delta 7$ mutation is broadly consistent with the presence of diabetes in the family (Fig. 4). The proband has seven siblings and a mother who is still living. Of the family members six carry the $\Delta 7$ mutation: the mother, the proband, two sisters and two brothers. Of these $\Delta 7$ positive family members all have diabetes except for one sister. This sister (age 45, BMI
44.6) has a high normal $\mathrm{Hb} 1_{\mathrm{Ac}}$ and could progress to frank diabetes in the future. There were three siblings who did not inherit the $\Delta 7$ mutation and one of these has Type II diabetes. Age of diagnosis for affected family members ranges from $39-67$ years which is more consistent with Type II diabetes than with MODY. The proband and his four diabetic siblings are currently treated with oral hypoglycaemic agents or dietary control. There was one, the mother, who was unaware of her diabetes and was not receiving any treatment. No member of the family has received insulin therapy. In addition to the segregation of the $\Delta 7$ mutation in the family, the major clinical observation was the considerable obesity in the family with six siblings and the mother having BMIs greater than 40. Of the siblings four with the $\Delta 7$ mutation had either microalbuminuria or overt nephropathy or endstage renal disease or both suggesting the possibility that $\Delta 7$ can confer a particularly severe form of Type II diabetes causing renal target organ damage.

\section{Discussion}

We have screened the $H N F 4 \alpha$ gene, including both coding and promoter regions, for mutations in a group of 182 Caucasian diabetic nephropathic patients who had a genetic association with the closely linked $A D A$ locus in an earlier study [30]. This study identified five previously reported polymorphsims or mutations, or both which are not considered to affect HNF4 $\alpha$ function $[6,20,21,38,39]$. We observed no statistically significant differences in the frequencies of these sequence variants between the Type II diabetic patients and control subjects. These data further support the hypothesis that these reported polymorphisms do not contribute to Type II diabetes susceptibility in this group. We identified two novel $H N F 4 \alpha$ mutations in the Type II diabetic group, one in the extreme carboxy terminal region of exon $8(\mathrm{R} 323 \mathrm{H})$ which awaits functional characterisation. This mutation was observed in one allele of one patient (age of onset 46 years, BMI 35.54) and not found in any of the 100 healthy control subjects. This mutation results in a semiconservative substitution in the carboxy terminal end of the HNF $4 \alpha$ protein. This amino acid is conserved in HNF4 isoforms from other species including Drosophila, Aedes aegypti, Bombyx mori, Xenopus, rat and mouse. All known isoforms of HNF $4 \alpha$ contain exon 8 but deletion studies have suggested that the extreme carboxy terminal domain of $\mathrm{HNF} 4 \alpha$ is not required for promoter binding or activation [45]. This does, however, not exclude a possible alteration of $\mathrm{HNF} 4 \alpha$ activity by the $\mathrm{R} 323 \mathrm{H}$ mutation.

The proximal promoter region of $H N F 4 \alpha$ contains binding sites for numerous transcription factors including AP1 (activator protein 1), HNF-3, HNF1 $\alpha$ 


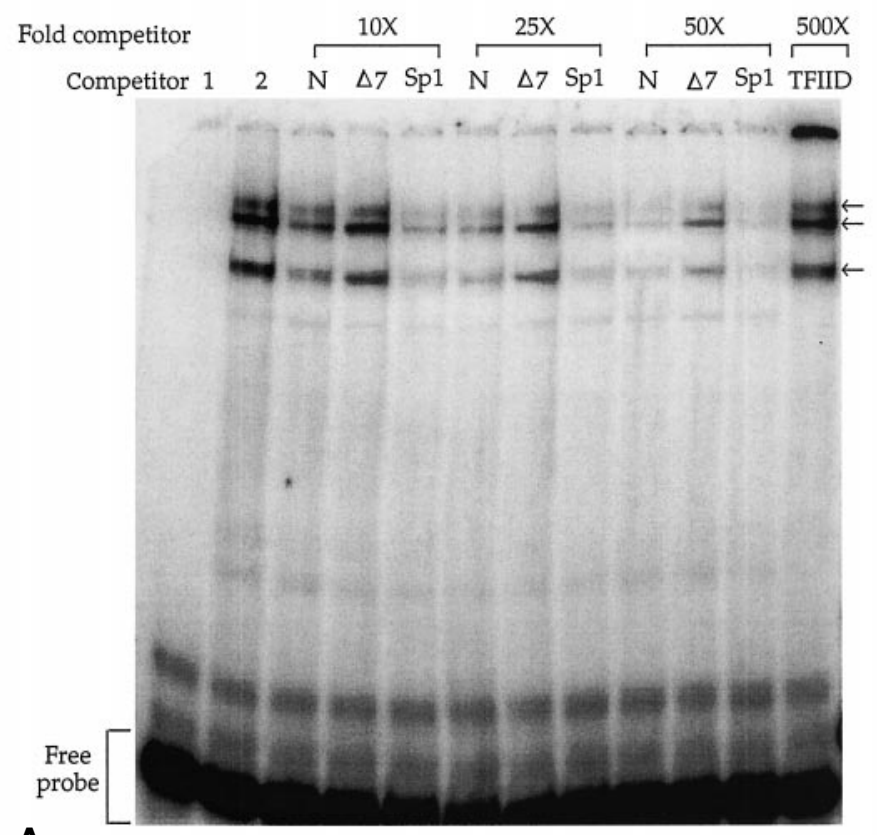

A

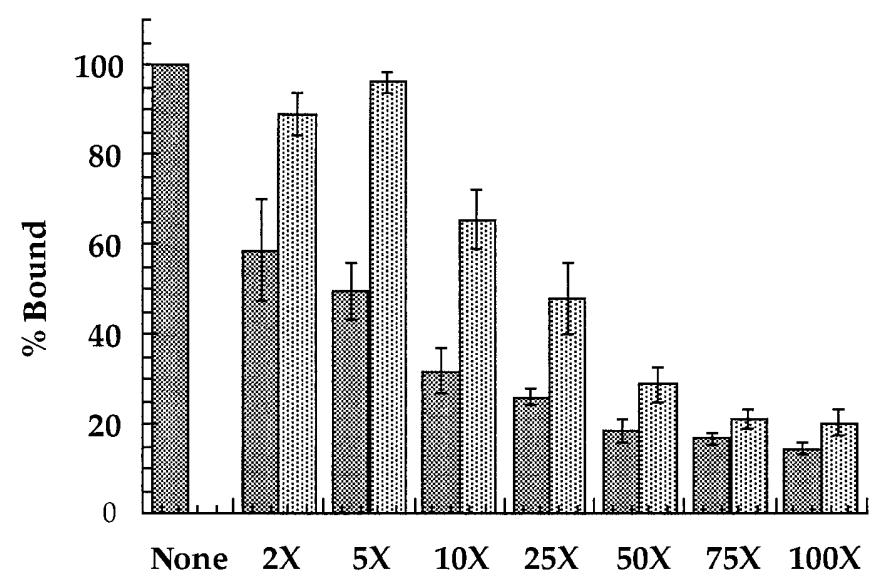

B

Fold competitor

Fig.3A-D. Electrophoretic mobility shift assay (EMSA) analysis of the normal and $\Delta 7 \mathrm{HNF} 4 \alpha$ promoter. A Competition of normal promoter sequence with normal $(\mathrm{N})$ promoter, $\Delta 7$ promoter, and Sp1 sequences. Lane 1 is the normal promoter sequence alone and lane 2 is the normal promoter sequence in the presence of HepG2 nuclear extract. The TFIID is normal promoter sequence in the presence of HepG2 nuclear extract and a non-specific competitor. B Quantitative analysis of competition of normal promoter DNA-protein complexes with increasing normal and $\Delta 7$ promoter competitor concentrations. Normal promoter sequence in the presence of HepG2 nuclear proteins is considered $100 \%$ bound. [I] normal promoter sequence, $\square \Delta 7$ promoter sequence. $\mathbf{C}$ Competition of consensus Sp1 binding site with normal promoter, $\Delta 7$ promoter and Sp1 sequences. D Quantitative analysis of competition of consensus Sp1 DNA-protein complexes with increasing normal and $\Delta 7$ promoter competitor concentrations. [1] normal promoter sequence, $\square \Delta 7$ promoter sequence

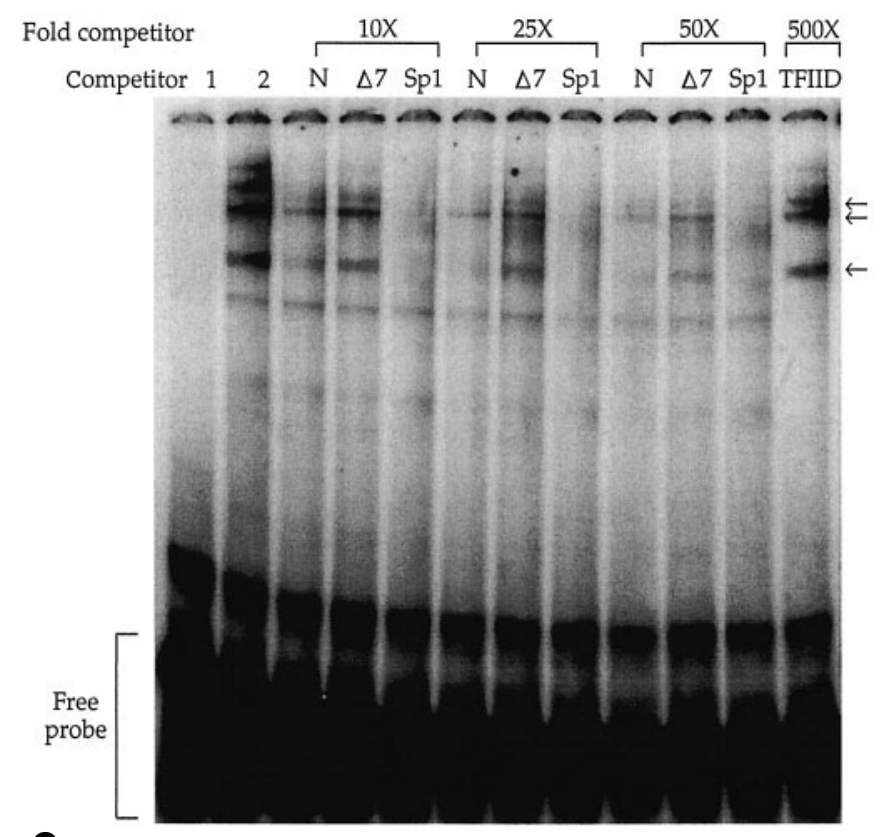

C

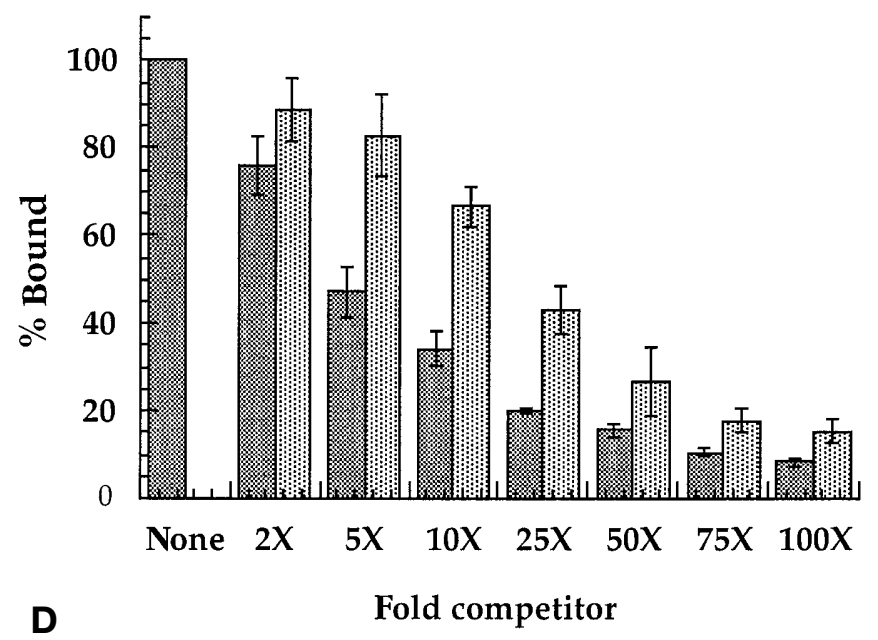

and NF-1 (nuclear factor 1) [17] that are conserved in mice and humans. In the Caucasian Type II diabetic subjects $(n=182)$ and control subjects $(n=100)$ in the current study, no mutations were identified in any of these sites. This is consistent with other studies of the promoter region of the $H N F 4 \alpha$ gene which have also failed to identify mutations in these conserved transcription factor binding sites $[20,38]$.

We did however identify a 7 bp deletion $(\Delta 7)$ in the proximal promoter region resulting in deletion of a single putative $\mathrm{Sp} 1$ binding site. This second novel mutation ( $\Delta 7$ promoter mutation) was characterised using both reporter assays and gel retardation assays which showed an average $50 \%$ reduction in activation and binding of the $\Delta 7$ mutation compared with the normal promoter sequence suggesting the mutation could have a pronounced effect on $H N F 4 \alpha$ gene expression. The $\Delta 7$ promoter mutation deletes one of two putative Sp1 transcription factor binding sites. Generally $S p 1$ is considered a ubiquitously expressed transcription fac- 

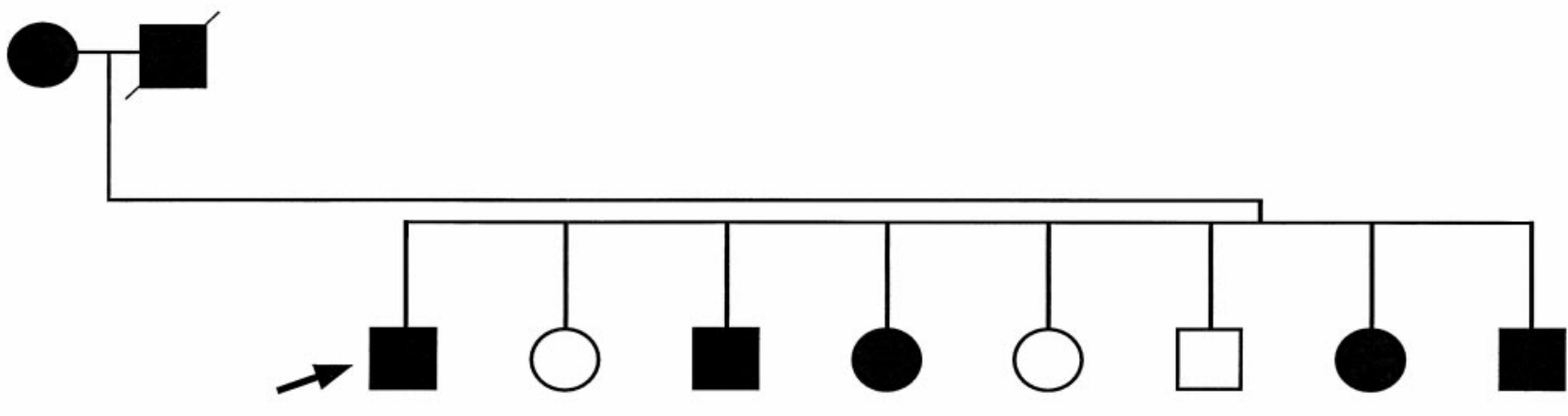
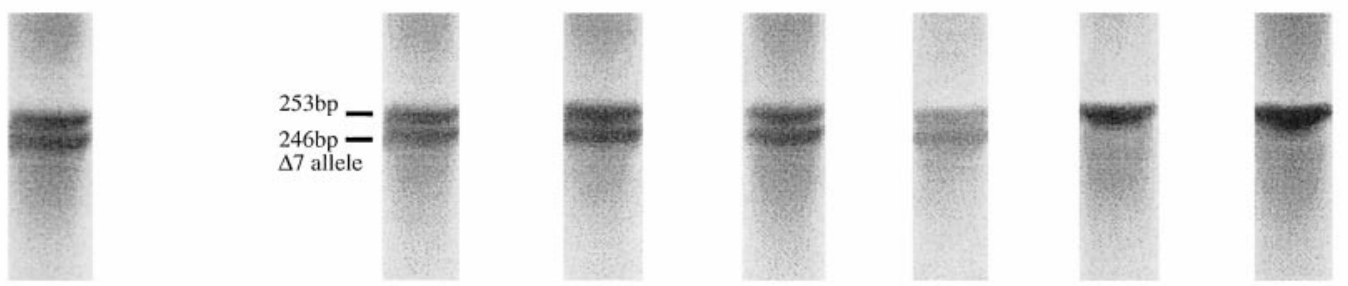

$\begin{array}{lll}\text { 64y.o. at death } & \text { Age } & 49 \\ \text { BMI 49.4 } & \text { BMI } & 49.4 \\ & \text { UPC } & 10000 \\ & \text { HbA }_{1 c} & 6.3 \% \\ & \text { DM Dx } & 35\end{array}$

$\begin{array}{ll}\text { Age } & 45 \\ \text { BMI } & 44.6 \\ \text { UPC } & 6 \\ \mathrm{HbA}_{1 \mathrm{c}} & 5.7 \% \\ \text { DM Dx } & \text { N/A }\end{array}$

\begin{tabular}{ll} 
Age & 46 \\
BMI & 50.4 \\
UPC & 467 \\
$\mathrm{HbA}_{1 \mathrm{c}}$ & $7.3 \%$ \\
\hline $\mathrm{DMD}$ & 46
\end{tabular}

DM Dx 46

Fig.4. Pedigree, genotype analysis of the $\Delta 7 H N F 4 \alpha$ deletion and relevant clinical data of WFUBMC 2137 family. The arrow indicates the proband with both Type II diabetes and end-stage renal failure. Open symbols represent unaffected family members and filled symbols represent those with clinically diagnosed Type II diabetes. The upper $253 \mathrm{bp}$ band is the wildtype PCR-SSCP allele and the smaller $246 \mathrm{bp}$ fragment is the 7 bp deletion allele. Relevant clinical data is listed beneath the genotype analysis: UPC: urinary protein concentrations ( $\mu \mathrm{g}$ per mg creatinine); $\mathrm{Hb} 1_{\mathrm{Ac}}$ : upper limit of normal is $5.9 \%$; and DMDx: age at Type II diabetes diagnosis

tor involved in the regulation of numerous eukaryotic and viral genes particularly those with TATA-less promoters [44]. Sequence similarity searching of the $14 \mathrm{bp}$ normal promoter sequence showed $100 \%$ identity to many gene promoter regions including: rat plateletderived growth factor A gene (PDGF-A), human calcium activated neutral protease large subunit $(\mathrm{mu}-$ CANP), human multiple exostosis 2 gene (EXT2), endomembrane proton pump subunit, mouse $t$ complex testis specific protein (Tctex2) and dog CD34. The low probability $(p<0.05)$ of detecting this 14 -base pair sequence in this context suggests that it is of some functional relevance.

Clustered or multiple Sp1 binding sites have been found in the promoter regions of many genes. The functional properties of repeated Sp1 binding sites has been evaluated in numerous studies. Deletion of four clustered $\mathrm{Sp} 1$ sites in the promoter region of the insulin receptor gene resulted in inefficient expression of the gene [42]. Binding of Sp1 to the three repeated Sp1 binding sites of the PDGF-A chain pro-

\begin{tabular}{|c|c|c|c|c|c|c|c|c|c|}
\hline & & & 43 & & & & 40 & & \\
\hline MI & 47.6 & $\begin{array}{l}\text { MI } \\
\text { PI }\end{array}$ & 34 & BMI & 25 & BMI & 43.2 & BMI & 44.6 \\
\hline & $\begin{array}{l}180 \\
8.9 \%\end{array}$ & $\begin{array}{l}\text { UPC } \\
\text { Hb }\end{array}$ & $5.6 \%$ & $\mathrm{db}$ & $5.0 \%$ & $\mathrm{~A}_{1 \mathrm{c}}$ & $\begin{array}{l}10 \\
6.3 \%\end{array}$ & & o \\
\hline
\end{tabular}

moter resulted in synergistic activation and suggested that cooperativity between bound $\mathrm{Sp} 1$ proteins is important in gene activation. Deletion of at least one of the three Sp1 binding sites resulted in a $70 \%$ reduction of promoter activity [41]. Additional support for the importance of repeated Sp1 binding sites is found in the $\alpha 2$-integrin gene promoter, which contains two repeated Sp1 sites. Deletion of one Sp1 binding site resulted in 80-90\% reduction in promoter activity, whereas the deletion of both Sp1 binding sites abolished promoter activity [43]. Our evaluation of the $\Delta 7$ promoter mutation, which deletes one of two Sp1 binding sites and results in a $50 \%$ reduction of promoter activity, is consistent with these studies.

The decrease in transcriptional activation of the $\Delta 7$ mutation is consistent with this mutation being associated with diabetes. Functional characterisation of the two previously identified premature termination mutations (Q268X, R154X) in MODY1 families, indicate that the diabetic phenotype is due to the loss of functional HNF4 $\alpha$ protein, as opposed to a gain of function from the mutant protein $[6,46]$. The loss of functional HNF $4 \alpha$ protein in the termination mutations is thought to be exacerbated in tissues where there is low HNF4 $\alpha$ expression (e.g. pancreas). Recent characterisation of the E276Q mutation suggests that haploinsufficiency as well as a weak dominant negative effect contribute to the Type II diabetic phenotype [46]. Our finding of a $50 \%$ reduction in activation and binding in the $\Delta 7$ promoter mutation is consistent with this hypothesis. It is not clear whether the patient with the $\Delta 7$ promoter mutation has MODY or conventional Type II diabetes. The patient's age of diagnosis is early (35 years) and the pa- 
tient has extreme obesity (BMI 44.2). We hypothesise that the $\Delta 7$-associated reduction in HNF4 $\alpha$ expression combined with obesity contributes to diabetes in this patient.

This hypothesis is largely supported by an evaluation of the family (WFUBMC 2137) of the proband. Of six family members with the $\Delta 7$ mutation five have diabetes and two of three family members without the $\Delta 7$ mutation do not have diabetes. The absence of complete correlation of the $\Delta 7$ mutation with diabetes is not surprising for a common, late-onset disease and consistent with the presentation of other families harbouring $H N F 4 \alpha$ mutations [21, 22]. The one $\Delta 7$ positive sibling without clinical diabetes has a high normal $\mathrm{Hb} 1_{\mathrm{Ac}}$ and could yet progress to overt diabetes. In addition, the one diabetic sibling who is $\Delta 7$ negative could easily have diabetes from another aetiology. The expression and EMSA studies suggest that the $\Delta 7$ mutation probably leads to a $50 \%$ reduction in expression of $\mathrm{HNF} 4 \alpha$ from the mutated chromosome, leading to a $25 \%$ reduction in the potential expression of $\mathrm{HNF} 4 \alpha$ in a cell. Because a $50 \%$ reduction in $\mathrm{HNF} 4 \alpha$ expression in people with protein truncation mutations leads to early-onset diabetes, it is not surprising that a $25 \%$ reduction in HNF $4 \alpha$ expression, associated with substantial obesity, in the WFUBMC 2137 family could lead to later-onset diabetes. This analysis of the $\Delta 7$ promoter suggests promoter mutations that alter the expression of diabetogenic genes, such as $H N F 4 \alpha$ have the ability to confer a disease phenotype in people carrying such alleles even though the coding sequence of the gene is normal.

The two new mutations described in this report (the $\mathrm{R} 323 \mathrm{H}$ in exon 8 and the $\Delta 7$ promoter mutation) are not sufficient to explain the evidence of linkage disequilibrium observed in our Type II diabetic nephropathic patient group. It should be noted that SSCP could have a detection rate of $80-90 \%$ [48] and thus, we might not have detected all DNA-sequence differences. It is, however, unlikely that such sequence differences would identify a substantial number of new mutations in the cohort we screened. The low number of mutations in the coding and proximal promoter region of $H N F 4 \alpha$ in the patient group which shows association with chromosome 20 is consistent with other studies [6, 20, 21, 38, 39]. Therefore, the question still remains, which gene or genes on chromosome 20 are contributing to Type II diabetes susceptibility? A possibility is that other Type II diabetic susceptibility gene(s), residing near $H N F 4 \alpha$, are responsible for the evidence of linkage and linkage disequilibrium of Type II diabetes to chromosome 20.

Acknowledgements. This work was supported by National Institutes of Health grant R01-DK41269 and R01-DK53591 (D. W. Bowden) and R01-HL56266 (B. I. Freedman). The authors greatly appreciate the technical guidance of G. Shellness and B. Yoza.

\section{References}

1. King H, Rewers M, WHO Ad Hoc Diabetes Reporting Group (1993) Global estimates for prevalence of diabetes mellitus and impaired glucose tolerance in adults. Diabetes Care 16: 157-177

2. Hanis CL, Boerwinkle E, Chakraborty R et al. (1996) A genome-wide search for human non-insulin dependent (type 2) diabetes genes reveals a major susceptibility locus on chromosome 2. Nat Genet 13: 161-166

3. Mahtani MM, Widen E, Lehto M et al. (1996) Mapping of a gene for type 2 diabetes mellitus associated with an insulin secretion defect by genome scan in Finnish families. Nat Genet 14: 90-94

4. Fajans SS (1990) Scope and heterogeneous nature of MODY. Diabetes Care 13: 49-64

5. Herman WH, Fajans SS, Ortiz FJ et al. (1994) Abnormal insulin secretion, not insulin resistance, is the genetic or primary defect of MODY in the RW Pedigree. Diabetes 43: 40-46

6. Yamagata K, Furuta H, Oda N et al. (1996) Mutations in the hepatocyte nuclear factor- $4 \alpha$ gene in maturity-onset diabetes of the young (MODY1). Nature 384: 458-460

7. Miller SP, Anand GR, Karschnia EJ, Bell GI, LaPorte DC, Lange AJ (1999) Characterization of glucokinase mutations associated with maturity-onset diabetes of the young type 2 (MODY2): different glucokinase defects lead to a common phenotype. Diabetes 48: 1645-1651

8. Yamagata K, Oda N, Kaisaki PJ et al. (1996) Mutations in the hepatocyte nuclear factor- $1 \alpha$ gene in maturity-onset diabetes of the young (MODY3). Nature 384: 455-458

9. Stoffers DA, Ferrer J, Clarke WL, Habener JF (1997) Early-onset type-II diabetes mellitus (MODY4) linked to IPF1. Nat Genet 17: 138-139

10. Horikawa Y, Iwasaki N, Hara M et al. (1997) Mutation in hepatocyte nuclear factor-1 beta gene (TCF2) associated with MODY. Nat Genet 17: 384-385

11. Stöffel M, Duncan SA (1997) The maturity-onset diabetes of the young (MODY1) transcription factor HNF4 $\alpha$ regulates expression of genes required for glucose transport and metabolism. Proc Natl Acad Sci USA 94: 13209-13214

12. Sladek FM (1994) Hepatocyte nuclear factor 4 (HNF4). In: Tronche F, Yaniv M (eds) Liver Gene Expression. Landes, Austin, pp 207-230

13. Hattersley AT (1998) Maturity-onset diabetes of the young: clinical heterogeneity explained by genetic heterogeneity. Diabet Med 15: 15-24

14. Vaxillaire M, Rouard M, Yamagata K et al. (1997) Identification of nine novel mutations in the hepatocyte nuclear factor 1 alpha gene associated with maturity-onset diabetes of the young (MODY3). Hum Mol Genet 6: 583-586

15. Kaisaki PJ, Menzel S, Lindner T et al. (1997) Mutations in the hepatocyte nuclear factor-1-alpha gene in MODY and early-onset NIDDM: evidence for a mutational hotspot in exon 4. Diabetes 46: 528-535

16. Hansen T, Eiberg H, Rouard M et al. (1997) Novel MODY3 mutations in the hepatocyte nuclear factor-1-alpha gene: evidence for a hyperexcitability of pancreatic beta-cells to intravenous secretagogues in a glucose tolerant carrier of a P447L mutation. Diabetes 46: 726-730

17. Gragnoli C, Lindner T, Cockburn BN, Kaisaki PJ, Gragnoli F, Marozzi G, Bell GI (1997) Maturity-onset diabetes of the young due to a mutation in the hepatocyte nuclear factor-4alpha binding site in the promoter of the hepatocyte nuclear factor-1-alpha gene. Diabetes 46: 1648-1651

18. Frayling TM, Bulman MP, Appleton M, Hattersley AT, Ellard S (1997) A rapid screening method for hepatocyte nu- 
clear factor 1 alpha frameshift mutations; prevalence in maturity-onset diabetes of the young and late-onset non-insulin dependent diabetes. Hum Genet 101: 351-354

19. Frayling TM, Bulman MP, Ellard S et al.(1997) Mutations in the hepatocyte nuclear factor-1-alpha gene are a common cause of maturity-onset diabetes of the young in the U. K. Diabetes 46: 720-725

20. Lindner T, Gragnoli C, Furuta H et al. (1997) Hepatic function in a family with a nonsense mutation (R154X) in the hepatocyte nuclear factor-4-alpha/MODY1 gene. J Clin Invest 100: 1400-1405

21. Furuta H, Iwasaki N, Oda N et al. (1997) Organization and partial sequence of the hepatocyte nuclear factor- $4 \alpha /$ MODY1 gene and identification of a missense mutation, R127W, in a Japanese family with MODY. Diabetes 46: 1652-1657

22. Hani EH, Suaud L, Boutin P et al. (1998) A missense mutation in hepatocyte nuclear factor- $4 \alpha$ resulting in a reduced transactivation activity, in human late-onset non-insulindependent diabetes mellitus. J Clin Invest 101: 521-526

23. Bulman MP, Dronsfield MJ, Frayling Tet al. (1997) A missense mutation in the hepatocyte nuclear factor 4 alpha gene in a UK pedigree with maturity-onset diabetes of the young. Diabetologia 40: 859-862

24. Moller AM, Dalgaard LT, Ambye L et al. (1999) A novel Phe75fsdelT mutation in the hepatocyte nuclear factor-4alpha gene in a Danish pedigree with maturity onset diabetes of the young. J Clin Endocrinol Metab 84: 367-369

25. Malecki MT, Yang Y, Antonellis A et al. (1999) Identification of new mutations in the hepatocyte nuclear factor 4alpha gene among families with early onset type 2 diabetes mellitus. Diabet Med 16: 193-200

26. Bowden DW, Sale M, Howard TD et al. (1997) Linkage of genetic markers on human chromosomes 20 and 12 to NIDDM in Caucasian sib pairs with a history of diabetic nephropathy. Diabetes 46: 882-886

27. Ji L, Malecki M, Warram JH, Yang Y, Rich SS, Krolewski AS (1997) New susceptibility locus for NIDDM is localized to human chromosome 20 q. Diabetes 46: 876-881

28. Zouali H, Hani EH, Philippi A et al. (1997) A susceptibility locus for early-onset non-insulin dependent (type 2) diabetes mellitus maps to chromosome $20 \mathrm{q}$, proximal to the phophoenolpyruvate carboxykinase gene. Hum Mol Genet 6: 1401-1408

29. Ghosh S, Watanabe RM, Hauser E et al. (1999) Type 2 diabetes: evidence for linkage on chromosome 20 in 716 Finnish affected sibpairs. Proc Natl Acad Sci USA 96: 2198-2203

30. Price JA, Brewer CS, Howard TD et al. (1997) Construction of a physical map of chromosome 20q12-13.1 and linkage disequilibrium analysis in diabetic nephropathy patients. Am J Hum Genet 61[Suppl]:A241 (Abstract)

31. Bench AJ, Aldred MA, Humphray SJ et al. (1998) A detailed physical and transcriptional map of the region of chromosome 20 that is deleted in myeloproliferative disorders and refinement of the common deleted region. Genomics 49: 351-362

32. Stoffel M, Le Beau MM, Espinosa R et al. (1996) A yeast artificial chromosome-based map of the region of chromo- some 20 containing the diabetes-susceptibility gene, MODY1, and a myeloid leukemia related gene. Proc Natl Acad Sci USA 93: 3937-3941

33. Price JA, Brewer CS, Howard TD et al. (1999) A physical map of the 20q12-13.1 region associated with Type 2 diabetes. Genomics 62: 208-215

34. Zhang J, Madden TL (1997) PowerBLAST: a new network BLAST application for interactive or automated sequence analysis and annotation. Genome Res 7: 649-656

35. Dawson PA, Hofmann SL, van der Westhuyzen DR, Sudhof TC, Brown MS, Goldstein JL (1988) Sterol-dependent repression of low density lipoprotein receptor promoter mediated by 16-base pair sequence adjacent to binding site for the transcription factor Sp1. J Biol Chem 263: 3372-3379

36. Lee F, Hall CV, Ringold GM, Dobson DE, Luh J, Jacob PE (1984) Functional analysis of the steroid hormone control region of mouse mammary tumor virus. Nucleic Acids Res 12: 4191-4206

37. Locker J, Buzard G (1990) A dictionary of transcription control sequences. DNA Seq 1: 3-11

38. Malecki MT, Antonellis A, Casey P et al. (1998) Exclusion of the hepatocyte nuclear factor $4 \alpha$ as a candidate gene for late-onset NIDDM linked with chromosome $20 \mathrm{q}$. Diabetes 46: 970-972

39. Moller AM, Urhammer SA, Dalgaard LT et al. (1997) Studies of the genetic variability of the coding region of the hepatocyte nuclear factor- $4 \alpha$ in Caucasians with maturity onset NIDDM. Diabetologia 40: 980-983

40. Kritis AA, Argyrokastritis A, Moschonas NK et al. (1996) Isolation and characterization of a third isoform of human hepatocyte nuclear factor 4. Gene 173: 275-280

41. Kagonaga JT, Jones KA, Tijan R (1986) Promoter-specific activation of RNA polymerase II transcription by $\mathrm{Sp} 1$. Trends Biochem Sci 11: 20-23

42. Lin X, Wang Z, Gu L, Deuel TF (1992) Functional analysis of the human platelet-derived growth factor A-chain promoter region. J Biol Chem 267: 25614-25619

43. Araki E, Murakami T, Shirotani T et al. (1991) A cluster of four Sp1 binding sites required for efficient expression of the human insulin receptor gene. J Biol Chem 266: 3944-3948

44. Zutter MM, Ryan EE, Painter AD (1997) Binding of phosphorylated Sp1 protein to tandem Sp1 binding sites regulates $\alpha 2$ integrin gene promoter activity. Blood 90: 678-689

45. Lania L, Majello B, De Luca P (1997) Transcriptional regulation by the $\mathrm{Sp}$ family proteins. Int J Biochem Cell Biol 29: 1313-1323

46. Sladek FM, Dallas-Yang Q, Nepomuceno L (1998) MODY1 mutation Q268X in hepatocyte nuclear factor 4a allows for dimerization in solution but causes abnormal subcellular localization. Diabetes 47: 985-990

47. Navas MA, Munoz-Elias EJ, Kim J, Shih D, Stoffel M (1999) Functional characterization of the MODY1 gene mutations HNF4(R127W), HNF4 (V255M), and HNF4(E276Q). Diabetes 48: 1459-1465

48. Hayashi K, Yandell DW (1993) How sensitive is PCRSSCP? Hum Mutat 2: 338-346 